\title{
Estudos de recepção para entender os usos da mídia na escola*
}

Roseli Fígaro**

Professora doutora na Escola de Comunicações e Artes da Universidade de São Paulo, com pós-doutorado na Universidade de Provence, França. Pesquisadora do grupo de pesquisa do Arquivo Miroel Silveira, bem como pesquisadora e coordenadora do grupo de pesquisa Comunicação e Trabalho ECA-USP/CNPq. Foi editora executiva da revista Comunicação \& Educação de 1995 a 2003.

Resumo: A autora trata da temática da recepção abordando tanto os meios de comunicação tradicionais quanto os novos meios viabilizados pela internet. Destaca que, se os dispositivos para a comunicação em massa segmentaram a produção e a recepção, simulando um receptor passivo, na atualidade, a web 2 e as redes sociais estão potencializando o processo comunicacional, prometendo dar visibilidade ao papel do sujeito como receptor/produtor de discursos. Defende os estudos de recepção como abordagem teórico-metodológica que permite ao pesquisador entender o papel dos meios de comunicação e como eles repercutem no cotidiano dos grupos sociais, nas diferentes comunidades e culturas. Os estudos de recepção possibilitam, no campo comunicação/educação, sair da oposição emissor todo-poderoso versus receptor passivo ou, por outro lado, da simulação emissor neutro versus receptor/consumidor todo-poderoso. As pesquisas com essa abordagem têm como objetivo compreender a comunicação como processo que se realiza na/pela interação de sujeitos determinados, históricos e que se inter-relacionam a partir de um contexto, compartilhando sistemas de códigos culturais; e, ao fazê-lo, atuam (agem), produzindo/renovando a sociedade.

Palavras-chave: comunicação, estudos de recepção, internet, escola.
Abstract: The author approaches the issue of reception dealing with traditional media and the new ones brought by Internet. She introduces the idea that, if mass media devices segmented production and reception, simulating a passive receptor, web. 2 and social networks are improving the communication process, giving visibility to the role of the subject as receptor/ producer of speeches. She advocates that the reception studies have a theoretical-methodological approach that allows the researcher to understand the function of media and how they reverberate in the daily life of social groups, communities and cultures. In the field of communication/education, the reception studies to go out of the opposition almighty transmitter versus passive receiver or, on the other hand, the simulation of neutral transmitter versus almighty receiver/consumer. These researches have as objective to understand communication as a process accomplished in and for the interaction of determined and historical subjects inside a context, sharing cultural codes systems and, by doing it, act producing/ renewing society.

Keywords: communication, reception studies, internet, school.

É comum ouvir críticas ao poder dos meios de comunicação, à mídia que deturpa e aliena. Feita a crítica, vem a prostração e nada mais resta senão

* Este ensaio me foi proposto para ser escrito tendo como base o artigo Estudos de recepção para a crítica da comunicação, publicado na revista Comunicação \& Educação, n. 17, p. 37-42, jan./abr. 2000. Nele também há aproveitamento de artigo da apresentação Intramuros e extramuros: a aventura do conhecimento!, publicado em Comunicação \& Educação, ano XIV, n. 2, p. 7-14, maio/ago. 2009.

** É autora dos livros: Relações de comunicação no mundo do trabaIho; Na cena paulista: o 
comunicação \& educação • Ano XV • número 3 • set/dez 2010

teatro amador. Circuito alternativo e popular de cultura (1927-1945) Comunicação e trabalho: estudo de recepção.

1. Pensador italiano, autor, entre outros, de Apocalípticos e integrados, publicado no Brasil em 1976 pela Editora Perspectiva.

2. É basicamente uma teoria sobre o rendimento ótimo da transmissão das mensagens, criada por engenheiros de telecomunicações na década de 1920.

3. O esquema informacional foi proposto por Claude Shannon, engenheiro da Bell System, em 1949, e trata da passagem do sinal (mensagem) da fonte de informação para transmissor e daí para um canal. Do canal, o sinal é captado por um receptor que decodifica a mensagem para o destinatário. desfrutar dos fugazes prazeres proporcionados pela condição de consumidor, abandonando a perspectiva crítica. Pode-se reconhecer nesse tipo de discurso a presença simultânea do que Umberto $\mathrm{Eco}^{1}$ denominou de apocalípticos e integrados para diferenciar funcionalistas frankfurtianos. Parece paradoxal, mas não é. Essa posição tem como consequência a perda da perspectiva que resulta do conjunto de atitudes que devem ser tomadas e assumidas pelo cidadão crítico. Ou seja, abandona qualquer responsabilidade para com a sociedade civil.

Por outro lado, se os dispositivos comunicacionais para a comunicação em massa segmentaram a produção e a recepção, simulando um receptor passivo, na atualidade, a web 2 e as redes sociais estão potencializando o processo comunicacional, porque possibilitam dar visibilidade ao papel do sujeito como receptor/produtor de discursos. $\mathrm{O}$ acesso à internet coloca à disposição de cada cidadão os meios para que amplie e dê visibilidade ao seu próprio ponto de vista. Falta garantir que todos tenham acesso não só aos meios eletrônicos, mas, sobretudo, às diferentes linguagens que lhes permitam aprender e conhecer.

Os estudos de recepção são abordagens teórico-metodológicas que possibilitam ao pesquisador entender o papel dos meios de comunicação na sociedade e como eles repercutem no cotidiano dos grupos sociais, nas diferentes comunidades e culturas. Permitem, no campo comunicação/educação, sair da oposição emissor todo-poderoso versus receptor passivo ou, por outro lado, da simulação emissor neutro versus receptor/consumidor todo-poderoso. As pesquisas a partir dos estudos de recepção têm como objetivo compreender a comunicação como processo que se realiza na/pela interação de sujeitos determinados, históricos e que se inter-relacionam a partir de um contexto, compartilhando sistemas de códigos culturais; e, ao fazê-lo, atuam (agem), produzindo/renovando a sociedade.

\section{COMUNICAÇ̃̃O VERSUS TRANSMISSÃO DE INFORMAÇỐES}

Para essa discussão ser consequente é preciso retomar a crítica à ideia de comunicação apenas como transmissão de informações.

A Teoria Matemática da Comunicação ${ }^{2}$ configura-se em importante avanço científico no que diz respeito à inserção das novas máquinas, dos computadores, da inteligência artificial. Mas é limitada para dar conta da análise da comunicação humana, na medida em que a entende de forma similar à transmissão de informações de uma máquina para outra, com o determinismo que tal compreensão acarreta. Essa linha teórica ganhou força no início do século $\mathrm{XX}$ e seu fundamento é a ideologia do progresso linear, tendo como base o desenvolvimento tecnológico.

A eficácia do esquema informacional ${ }^{3}$ para explicar a transmissão de informações entre emissor e receptor foi de tal maneira naturalizada que passou a 
Estudos de recepção para entender os usos da mídia na escola • Roseli Fígaro

ser adotada tanto pelas correntes críticas ${ }^{4}$ quanto pelas correntes funcionalistas ${ }^{5}$. E ainda hoje é hegemônica.

Os estudos de recepção colocam-se como abordagem teórico-metodológica capaz de extrapolar a explicação da comunicação como transmissão linear de informação, ou aquela baseada no reflexo, apoiada na psicologia behaviorista $^{6}$, comportamental, para problematizá-la como um fenômeno sociológico e cultural.

Outras correntes centram o estudo da comunicação nos meios, nos veículos. Para essas correntes, as tecnologias de informação e de comunicação são apresentadas como capazes de resolver todos os problemas da sociedade: a democratização, a liberdade de acesso, a inclusão social, o fim das desigualdades. Como se as tecnologias falassem por si mesmas, autônomas do corpo social, político, econômico, cultural do conjunto da sociedade.

Essas ideias encontram eco em discursos bastante elaborados. Pierre Lévy é um autor cuja produção acadêmica entende as tecnologias como redentoras de um devir mais humano. Um exemplo dessa posição de Lévy foi publicado em artigo, na Folha de S. Paulo, em 1998, com o título Revolução virtual. A cibercultura é hoje herdeira legítima das ideias progressistas do Iluminismo ${ }^{7}$. Nele o autor alerta para uma nova era tecnológica que permitiria a todo mundo desenvolver novos acessos, pois os meios de comunicação nos remeteriam a um momento pleno no qual os ideais do Iluminismo, ou seja, os ideais de liberdade, fraternidade e igualdade, seriam retomados como o manifesto da cibercultura. Para Arturo Escobar, cibercultura tem como pano de fundo as novíssimas tecnologias, em especial as relacionadas à comunicação digital, à realidade virtual e à biotecnologia. A natureza desta definição faz com que a cibercultura seja considerada a partir da perspectiva da análise da tecnologia, passando a abranger os fenômenos associados às novas tecnologias de ponta e à nova tecnologia intelectual engendrada pelo computador ${ }^{8}$. Caso se feche os olhos para a realidade, pode-se tomar a afirmação de Lévy como verdadeira, mas as tecnologias são projetadas e acionadas por um modelo de sociedade e de relações sociais, cujas lógicas atendem às estratégias para a manutenção do status quo. Nem mesmo a plenitude dos acessos é capaz de instalar os valores do racionalismo Iluminista.

No entanto, isso não significa negar a importância das tecnologias de informação e de comunicação. Nem apocalípticos nem integrados; nem naturalizar os novos meios de comunicação nem negá-los.

Então qual é o ponto de vista que se pode adotar para pensar o processo de comunicação?

Há de se voltar à cultura, à ideia de sujeito e de relações sociais. É preciso mostrar como essas linguagens são construídas, dar a conhecê-las, tornar a informação conhecimento ${ }^{9}$. Sem pensar a comunicação como processo de inter-relação, não se pode entender o que se passa na atualidade, principalmente com relação ao protagonismo que se espera no uso das novas mídias digitais e nas denominadas redes sociais. A escola tem importância nessa discussão.
4. São chamados de críticos os intelectuais da Escola de Frankfurt: Theodor Adorno, Max Horkheimer, Walter Benjamim, entre outros. Ver: MATTELART, Armand. História das teorias de comunicação. São Paulo: Loyola, 1998.

5. A escola funcionalista de origem norte-americana teve como fundadores H. Lasswell, P. Lazarsfeld, entre outros. Cf. MATTELART, op. cit.

6. Essa corrente da Psicologia defende que se podem estudar os conteúdos psicológicos por meio das suas manifestações observáveis, colocando o comportamento humano como representação da adaptação do homem ao ambiente, que pode ser decomposto em sequências explícitas: o estímulo, a resposta, o reforço.

7. LÉVY, Pierre. Revolução virtual. A cibercultura é hoje herdeira legítima das ideias progressistas do lluminismo. Folha de S. Paulo. 16 ago. 1998. Caderno Mais, p. 3.

8. Cf. GUIMARÃES JR. Mário José Lopes. Cibercultura e o surgimento de novas formas de sociabilidade. Trabalho apresentado no GT "Nuevos mapas culturales: Cyber espacio y tecnología de la virtualidad", na II Reunión de Antropología del Mercosur, Piriápolis, Uruguai, de 11 a 14 de novembro de 1997: ESCOBAR Arturo. Welcome to Cyberia: notes on the Anthropology of Cyberculture (Bem-vindos à Cyberia: comentários sobre a antropologia da cibercultura). Current Anthropology, v. 35, n 3, jun. 1994. Disponível em: <http://www.cfh.ufsc. br/ guima/ciber.html\#n4> Acesso em: 30 jun. 2010.

9. Sobre o tema, cf.: BACCEGA, M. Conhecimento, 
comunicação \& educação • Ano XV • número 3 • set/dez 2010

\section{DEMOCRATIZAÇÃO DOS MEIOS}

O tema da democratização dos meios de comunicação passa por dois tipos de abordagens: pela participação das comunidades na elaboração das políticas e da legislação que regulam a concessão e a posse dos meios de comunicação (sobretudo para questionar qual é o compromisso legal das empresas de comunicação com a sociedade civil, ao utilizarem-se de uma concessão pública); e pela discussão do direito de as comunidades usarem, elas mesmas, o espaço de radiodifusão.

Pouco preparo existe e pouca importância se dá para essa discussão; principalmente, é difícil encontrá-la nas salas de aula. Na sociedade contemporânea, eminentemente tecnológica, todas as informações - da simples ligação telefônica à transmissão de sinais para o vídeo - são transmitidas por meio das telecomunicações. Como, nesse jogo de forças entre os mercados e os blocos econômicos, abrir mão da discussão sobre a propriedade dos meios de comunicação, das tecnologias e do direito de acesso aos bens culturais provenientes desse momento de grande ebulição e de mudanças na produção cultural? Talvez no enfrentamento dessa discussão possa se desafiar a lógica de exclusão imposta pelo poder econômico e se praticar a revolução virtual proposta por Lévy, mas fica claro que esse é um debate que se trava no nível do poder político.

Para definir um pouco mais esse tema, é preciso enfrentar a discussão das empresas de mídia como produtoras de conteúdos. A abordagem dos estudos de recepção permite entender que os produtos culturais são resultantes de contradições que se instalam nas próprias empresas de comunicação que os produzem; resultam do processo contraditório de disputas de pontos de vista (estéticos, de conteúdos etc.) presentes na sociedade, o que lhes atribui um caráter polissêmico.

Essas expressões culturais não têm, necessariamente, um discurso homogêneo, porque existem as contradições no próprio meio que as produz. A telenovela é um exemplo. Produto cultural de maior penetração da televisão brasileira, ela consagrou-se a partir da experiência do início dos anos 1970, período mais duro da ditadura militar, quando dramaturgos como Lauro César Muniz, Benedito Ruy Barbosa, Dias Gomes foram para a Rede Globo. A censura os impedia de produzir para o teatro e eles passaram a escrever telenovelas, e, dentro do espaço que possuíam na rede de televisão, questionavam o que a própria ditadura queria impor. Tentaram e conseguiram criar uma nova linguagem para a telenovela, muitas vezes interpelando, por meio de metáforas, o momento político.

Martín-Barbero afirma que a comunicação é questão de mediações. Os

informação e tecnologia. Comunicação \& Educação, Brasil, v. 4, n 11, 1998. Disponível em: $<$ http://www.revistas. univerciencia.org/index. php/comeduc/article/ view/4062>. Acesso em: 30 jun. 2010. p. 7-16 meios de comunicação são mediadores entre nós e a realidade. Mas não só eles. Os diferentes grupos e instituições sociais, o mundo do trabalho e o cotidiano concreto vivido atuam como mediadores no processo comunicacional. A todo momento os discursos sociais se cruzam, se debatem, e é a partir deles que se formam os pontos de vista, que podem ser, mais ou menos, críticos a depender das oportunidades de acesso a visões diferentes daquelas que se apresentam 
Estudos de recepção para entender os usos da mídia na escola • Roseli Fígaro

como hegemônicas. O discurso da religião, o discurso dos partidos políticos, o discurso da família, da escola, eles estão aí, não são só os meios de comunicação a atuarem como agências formadoras de opinião.

\section{ESCOLA COMO MEDIADORA}

Nós professores também somos mediadores. Constituímos e podemos ter o poder de constituir uma expressão relevante, de dar ao discurso escolar a força de ser um mediador diferenciado, porque nele há potencial para isso. $\mathrm{O}$ professor está a todo momento recebendo o retorno do seu discurso, ele exercita a comunicação face a face e vê quanto é diferente esse retorno. O professor é alguém que, no seu dia a dia, interage com os desafios da formação e do futuro do jovem como cidadão. Os professores também são representantes do discurso da instituição escolar, mas as contradições e a diversidade de realidades que se apresentam em relação ao aluno estão muito mais próximas, estão à flor da pele.

Há que se valorizar essa proximidade e atuar para ser um polo importante de mediação. A escola pode recuperar sua relevância como mediadora social, principalmente em relação aos jovens, ao abrir-se para acolher as iniciativas de protagonismo da sociedade civil.

Os estudos de recepção colaboram no questionamento de práticas maniqueístas. É pouco proveitoso o discurso que sacramenta a mídia como ótima e a traz para a sala de aula sem nenhum senso crítico, isto é, sem vinculá-la à realidade mais geral da sociedade, usando-a apenas como instrumento, como ferramenta; ou, ao contrário, o discurso que a inviabiliza como possibilidade de estudo crítico a ser levado para a sala de aula, baseado na prerrogativa de que os meios de comunicação são instrumentos de alienação.

É preciso ampliar o campo de visão. Ver os meios de comunicação também como produtos do trabalho social. Por isso, uma outra discussão que se faz necessária na atualidade é sobre a categoria trabalho, pois é ela a categoria norteadora do que acontece no mundo contemporâneo. O sujeito social se constitui na e pela atividade de comunicação e de trabalho. O sujeito é construído no processo sociocultural. Ele é produtor de cultura e produto da cultura. É essa compreensão que permite a formação de uma visão humanística e crítica da sociedade.

\section{EXEMPLOS DO PROCESSO DE RECEPÇÃO}

Um bom exemplo do que se está discutindo pode se ter na análise do filme Entre os muros da escola ${ }^{10}$. A narrativa se passa numa escola pública francesa, cuja clientela é basicamente formada por filhos de imigrantes de distintas nacionalidades. $\mathrm{O}$ embate entre a identidade francesa $\mathrm{e}$ as comunidades de primeira geração nascidas na França é materializado no ensino da língua francesa. $\mathrm{O}$ filme questiona o discurso pedagógico do professor e a hierarquia
10. Entre os muros da escola, filme francês de Laurent Cantet, é uma adaptação do livro homônimo de François Bégaudeau, que também atuou como protagonista do filme, juntamente com os alunos, todos em primeira experiência como atores. Recebeu o prêmio de Cannes como melhor filme de 2008, foi indicado ao Oscar de melhor filme estrangeiro e venceu como melhor filme o prêmio Lumière. 
11. BAKHTIN, Mikhail (Voloshinov). Marxismo e filosofia da linguagem. São Paulo: Hucitec, 1988. cap. VI.

12. LíNGUA: vida em Português. Direção de Victor Lopes. Brasil/Portugal: TV Zero/Zambascope/Costa do Castelo, 2004. 1 DVD (105 min). de poder desse discurso. Há uma tensão constante entre professor e aluno, a qual aumenta quando o mestre sente que sua autoridade pode ser rebatida. As perguntas e os problemas que os alunos vão apresentando tratam da questão da identidade - os franceses e os não franceses; ter nascido na França e não ser reconhecido nem se sentir francês. Este aspecto aparece, principalmente, no uso da língua e na dúvida de a norma culta ser a única correta e verdadeira.

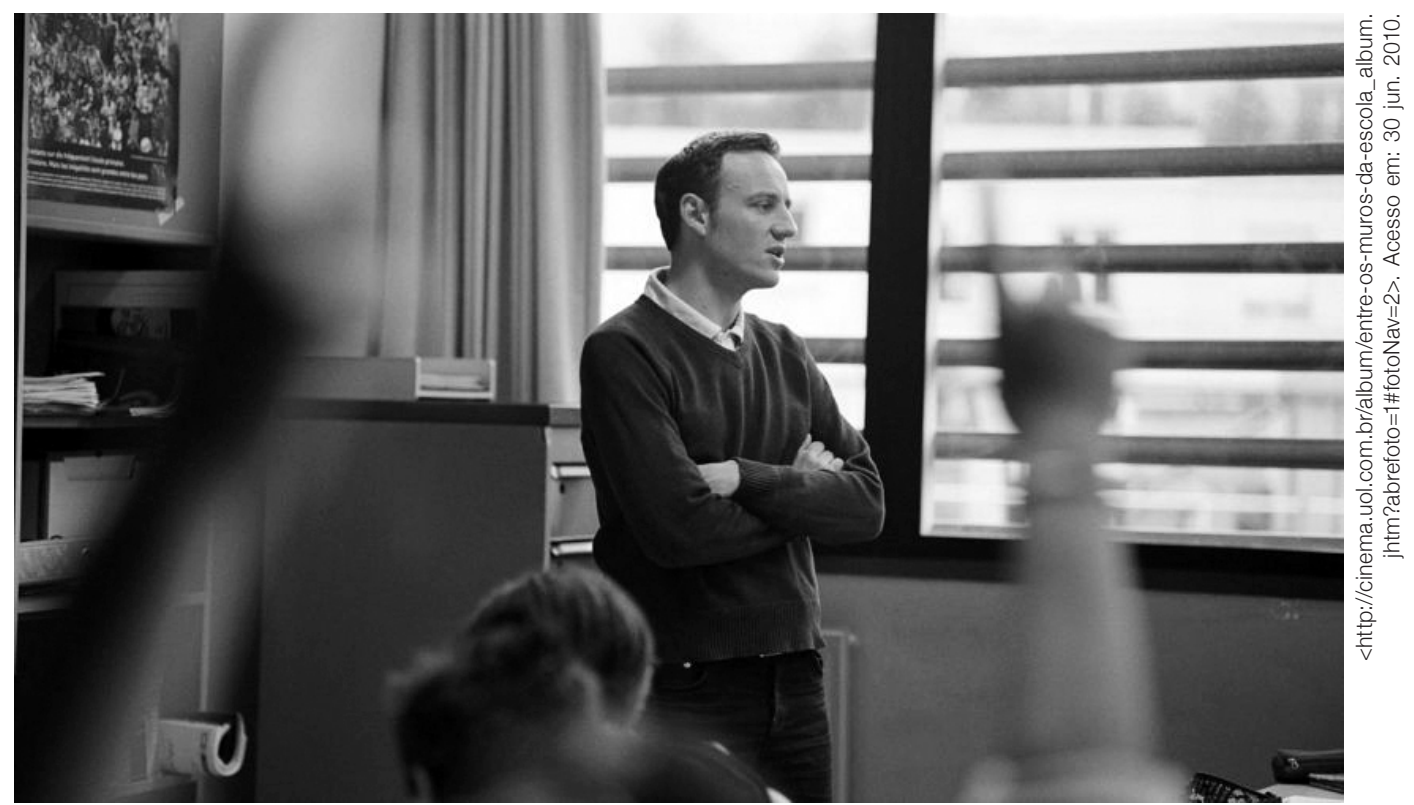

Com roteiro desenvolvido a partir do livro homônimo do professor François Bégaudeau, ele mesmo interpreta o papel do professor, cercado de alunos também reais,

todos eles recriando situações efetivamente vividas por todos, ainda que parcialmente, em salas de aula.

A língua é índice de poder. Ela revela a trajetória da experiência da vida intelectual de um falante. Como signo que se constitui e se atualiza na interação verbal ${ }^{11}$, demanda e remete à densidade da história e da cultura de uma comunidade. Produto das relações humanas numa dada organização social, a relação língua/sociedade permite identificar as variações e variedades de uma mesma língua em situação real de fala. Nessa acepção, a língua é matéria da vida, das relações sociais e, assim sendo, é dinâmica, mudancista, afeita aos trancos e barrancos do cotidiano. Há, portanto, numa mesma língua, muitas línguas, ou como José Saramago diz em seu depoimento ao filme Lingua: vidas em português, de Victor Lopes, "não há uma língua portuguesa, mas línguas em português"12. Talvez se possa parafrasear Saramago para afirmar que Entre os muros da escola quer mostrar que o Velho Continente se renova com outras identidades, outras culturas que trazem às línguas nacionais a tensão que a sociedade tradicional e o poder hegemônico não admitem. A batalha que se dá entre os muros da escola é uma luta de disputa pelos significados, pela fala, pelo direito de enunciar, a partir de um dado de realidade que o poder escolar instituído não reconhece. Se o permite, é sempre de forma simulada, de acordo com os padrões estabelecidos pelas normas que regulamentam, por exemplo, no 
Estudos de recepção para entender os usos da mídia na escola • Roseli Fígaro

caso do filme, o Conselho de Escola, o qual avalia e julga o desempenho dos alunos. A fala do banlieue não é permitida, não tem tradução, nem permissão para entrar na escola. Mas ela está lá com seus falantes. Quando o professor é questionado sobre por que e para que aprendem uma língua que não falam, que não usam (o subjuntivo pretérito), a resposta fica aquém do necessário. $\mathrm{O}$ professor limita-se a reafirmar a exigência de se aprender o francês-padrão, bem como reconhecer que, algumas vezes, o seu uso pode parecer pedante, esnobe. Ou, como mais bem definido pelo personagem do aluno: é a fala do burguês!

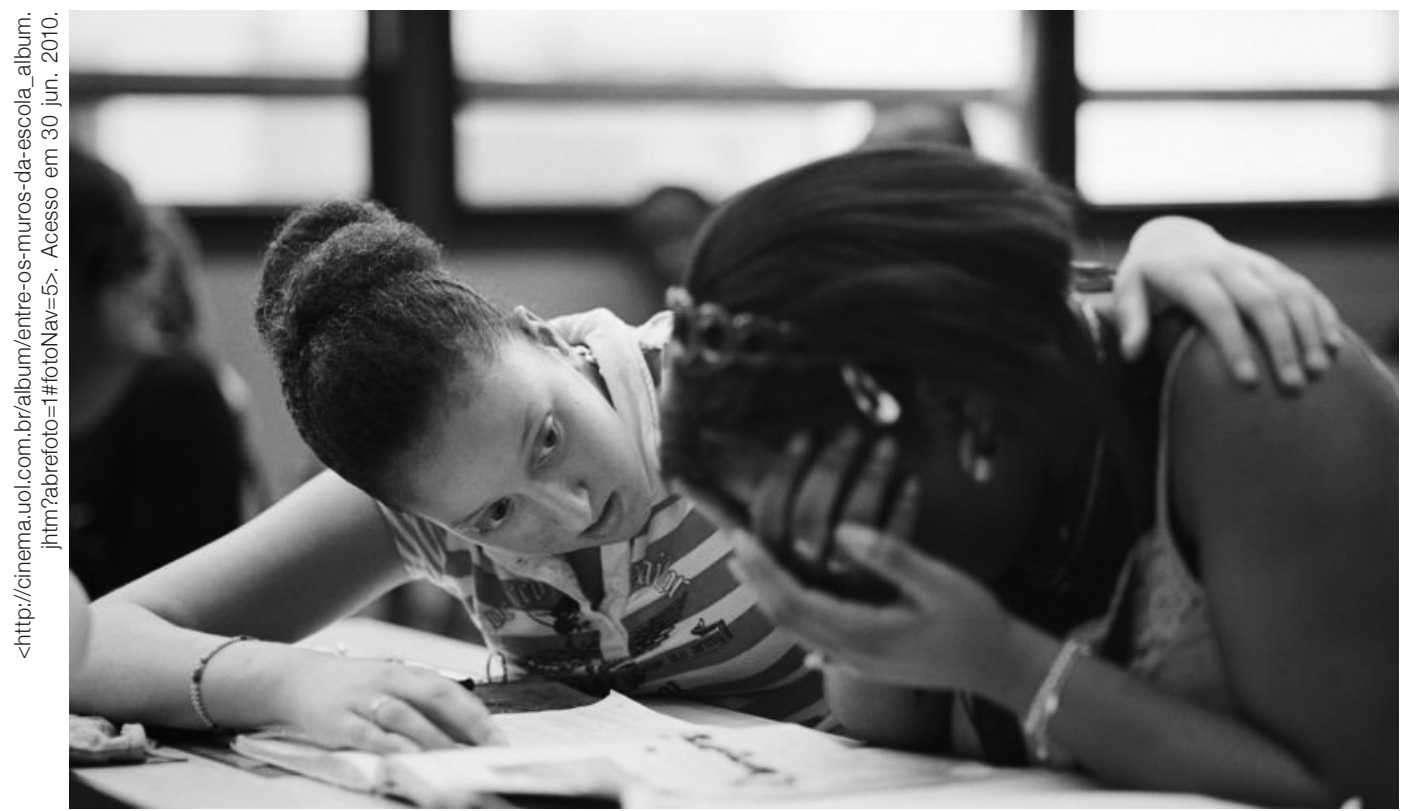

Entre os dilemas do professor, uma classe cheia de alunos de 14 e 15 anos, das mais diversas etnias, religiões e condições econômicas. A linguagem, necessária para o exercício da cidadania, termina detonando um conflito profundo, envolvendo o professor e a rebeldia de alunos.

O professor não está preparado para encarar o processo de ensino/aprendizado como propõe Paulo Freire, no clássico Pedagogia do oprimido ${ }^{13}$, partindo da realidade do aluno e levando-o ao contato com outras realidades, sem preconceitos e sem menosprezar a experiência de cada um.

A norma culta da língua é uma maneira de expressão e depende da situação de enunciação. Portanto, nem o subjuntivo pretérito do francês é pedante e inútil, como também não o são as formas verbais e o vocabulário da norma do dialeto popular. Faltou ao professor do filme explicar ao aluno, curioso e corretamente contestador, a obrigatoriedade do uso de uma norma, a importância de se transitar pelos diferentes níveis de fala, de capacitar-se para o exercício da diglossia e de, portanto, dominar as diferentes normas da língua que circulam na sociedade como sinônimo de poder. O papel da língua é a comunicação; regular seu funcionamento é atribuição dos falantes na sociedade. Entre grupos e culturas tão diferentes, num mesmo espaço urbano, é mais do que natural que haja variedades, configurando dialetos os quais constituem normas da língua e permitem a comunicação entre os membros de uma mesma comunidade linguística.

13. FREIRE, Paulo. Pedagogia do oprimido. 17. ed. Rio de Janeiro: Paz e Terra, 1987. 
comunicação \& educação • Ano XV • número 3 • set/dez 2010

O professor errou porque não permitiu ao aluno saber que o uso de seu dialeto, a fala do banlieue, tem valor, pois possibilita a comunicação e a expressão das particularidades de seu grupo social. No entanto, isso não basta! A vida na sociedade contemporânea é complexa e coloca em contato identidades diferenciadas, o que requer conhecimento e transmissão de outros dialetos sociais, inclusive o dialeto culto, portador do status de padrão correto da língua. O correto também é relativo: correto em que situação de fala, em intercâmbio com quais grupos e para manifestar quais expressões e interesses? Ou seja, o que se pretende ressaltar da análise da prática pedagógica ilustrada pelo filme é que a escola, como instituição de regulação, de organização das informações, a partir de determinado ponto de vista, está sendo contestada.

Não se trata de negar a necessidade de os currículos escolares estarem voltados ao conteúdo. Muito ao contrário. Trata-se de enfrentar a falsa dicotomia entre transmitir o conhecimento já construído e construir o conhecimento junto com. Visto que o conhecimento, como bem define Adam Schaff ${ }^{14}$, é a condição de transformar a informação a partir da própria experiência. O conhecimento é o pensamento particularmente qualificado, ou seja, é o produto da descrição (fatos e suas correlações) da realidade. Está relacionado com a vida concreta objetiva e a condição de abstração e generalização do pensamento. Condição essa a ser adquirida na escola, ao se aclararem para os alunos os porquês e em quais valores passarão a ser investidos ao terem acesso à norma culta e aos demais conteúdos relativos a cada período escolar. Isso posto, pode-se passar adiante, afirmando, como Schaff, que a língua é um aprendizado e uma experiência adquirida na sociedade e em suas instituições.

A reflexão que o filme permite é uma das possibilidades proporcionadas pelos estudos de recepção e traz desdobramentos concretos para o pesquisador interessado na escola, visto que aponta problemas concretos que deveriam ser discutidos entre os profissionais da educação.

Outro tema a que remete o filme diz respeito à identidade. A grande maioria dos alunos representados pertence a famílias provenientes de diferentes países da África e da Ásia. São várias etnias e diversos grupos sociais que também têm dificuldades em se reconhecer mutuamente. De comum possuem o fato de não serem considerados franceses e residirem em locais que os identificam e os estigmatizam.

14. SCHAFF, Adam. Linguagem e conhecimento. Coimbra: Almedina, 1974

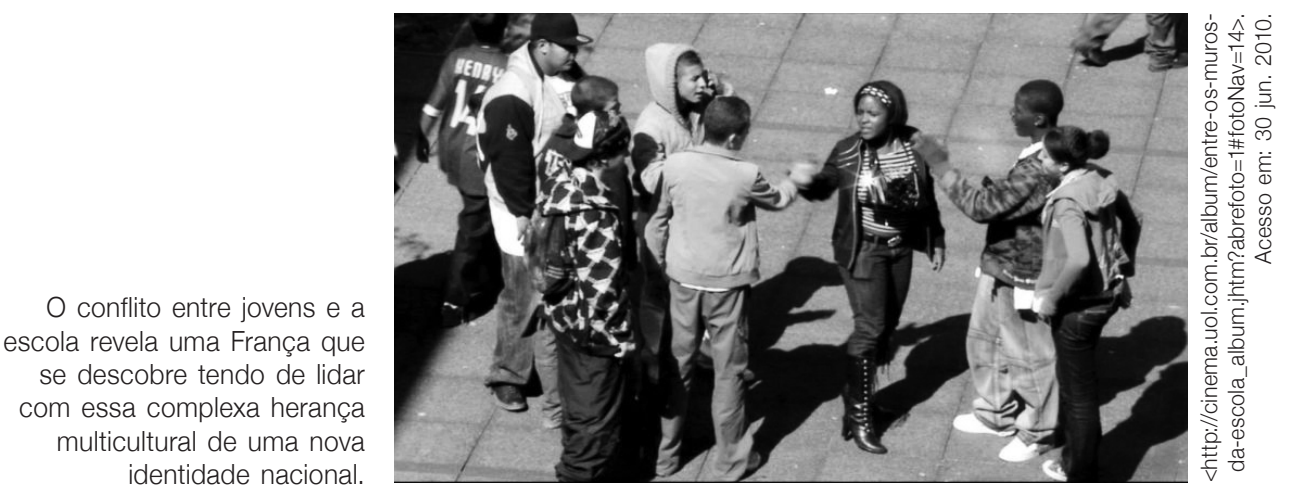


Estudos de recepção para entender os usos da mídia na escola • Roseli Fígaro

Para tratar dessa questão, no filme, o professor propõe a redação do autorretrato. A polêmica se dá porque ele exige que cada um se revele. Para quê? Por que dizer de si para os outros? Eles expressam sentimentos de baixa autoestima. O melhor resultado que o professor obtém é do aluno mais rebelde, Souleymane. No laboratório de informática, o jovem utiliza os recursos do computador para enunciar o discurso sobre si mesmo a partir da combinação da linguagem verbal e da não verbal, compondo imagens e legendas que retratam pessoas de sua família, os colegas da escola e a si próprio, destacando seu corpo: rosto, braço, tatuagem no ombro; lugar de inscrição de um discurso, primeiro elemento que o introduz na cena por meio da palavra.

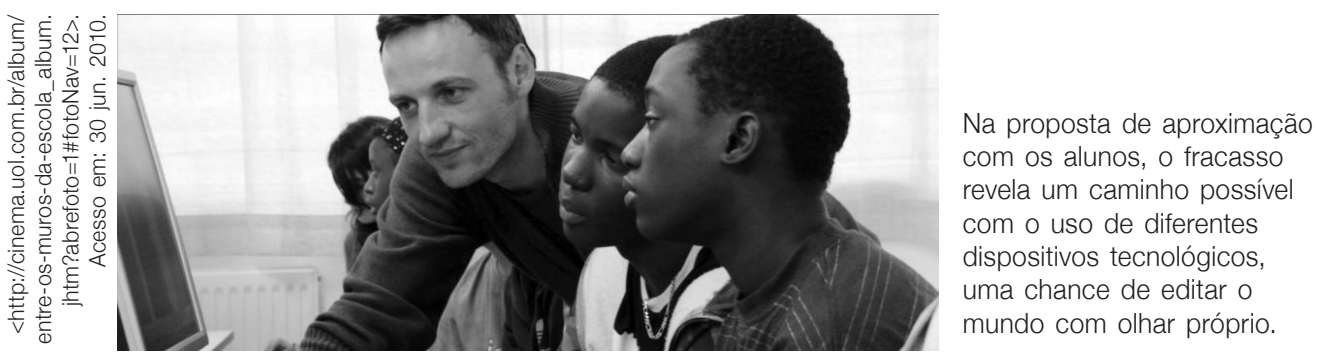

O acerto do professor na maneira de encaminhar e valorizar a produção daquele aluno é um exemplo de como as diferentes linguagens estão na escola. O uso do computador, da máquina fotográfica e o processo de composição e de edição mobilizam a experiência que vem de fora em proveito de novos conteúdos a serem adquiridos. Souleymane aprende a legendar, a dar a voz a cada foto que organiza, compondo o discurso sobre si e sobre os outros que fazem parte de seu mundo. Ele está trilhando o processo de criação editorial. Chegou a vez de ele propor e não apenas receber o mundo que lhe chega edi$\operatorname{tado}^{15}$, não só pelo livro escolar, mas sobretudo pelos meios de comunicação. E esse é o gancho para se discutir com os professores o processo de recepção e, por que não dizer, de como os discursos que circulam na sociedade fazem sentido para cada um de nós.

Outro exemplo pode ser retirado da análise do filme Quem quer ser um milionário ${ }^{16}$, de Danny Boyle, que mostra como um jovem indiano, nascido na maior favela de Mumbai, depois de perder a mãe, ser explorado por traficantes de crianças e chegar ao emprego de servente de chá numa empresa de telemarketing, vira celebridade ao participar e ganhar o prêmio máximo num programa de perguntas e respostas na TV. Ele dizia nada saber, mas foi respondendo corretamente uma a uma as questões que lhe foram feitas pelo apresentador.

A cada resposta, tem-se um trecho da história da vida de Jamal. Tal qual o conto das mil e uma noites, sua narrativa vai revelando um ponto de vista totalmente oposto ao do ambiente do auditório de TV e ao do tema da pergunta que lhe é feita. As perguntas e as alternativas de resposta são enunciadas pelo apresentador do programa. São como pistas para o jovem puxar da memória a solução, que ele não sabe se é certa, porém funciona como palavra-chave

15. BACCEGA, M. Do mundo editado à construção do mundo. Comunicação \& Educação, Brasil, v. 1, n. 1, 1994. Disponível em: <http://www.revistas. univerciencia.org/index. php/comeduc/article/ view/3867>. Acesso em: 17 jun. 2009.

16. Quem quer ser um milionário? (2008), dirigido pelo inglês Danny Boyle e totalmente filmado na Índia, ganhou oito Oscars, inclusive o de melhor filme. Foi inspirado no livro de Vikas Swarup, Sua resposta vale um bilhão. Traz referências à vida cotidiana da população pobre, sobretudo das crianças indianas. Pode ser lido, também, como uma homenagem a Bollywood, a indústria cinematográfica de Mumbai. 
comunicação \& educação • Ano XV • número 3 • set/dez 2010

para rever sua vida. Por exemplo, a resposta correta do nome de um cantor famoso é obtida a partir de um dos nomes apresentados, o qual o faz lembrar de sua infância na favela. $\mathrm{O}$ nome do cantor passa a ter sentido porque o liga à lição de coragem e de força de vontade que aprendeu em determinado dia. Ou então o nome do presidente norte-americano, cuja imagem está na nota de cem dólares, que lhe vem à memória não porque saiba a resposta certa, mas porque o nome remete-o a uma experiência de dor, desespero e tristeza com um velho amigo, que pede esmolas sob as garras dos exploradores de crianças.

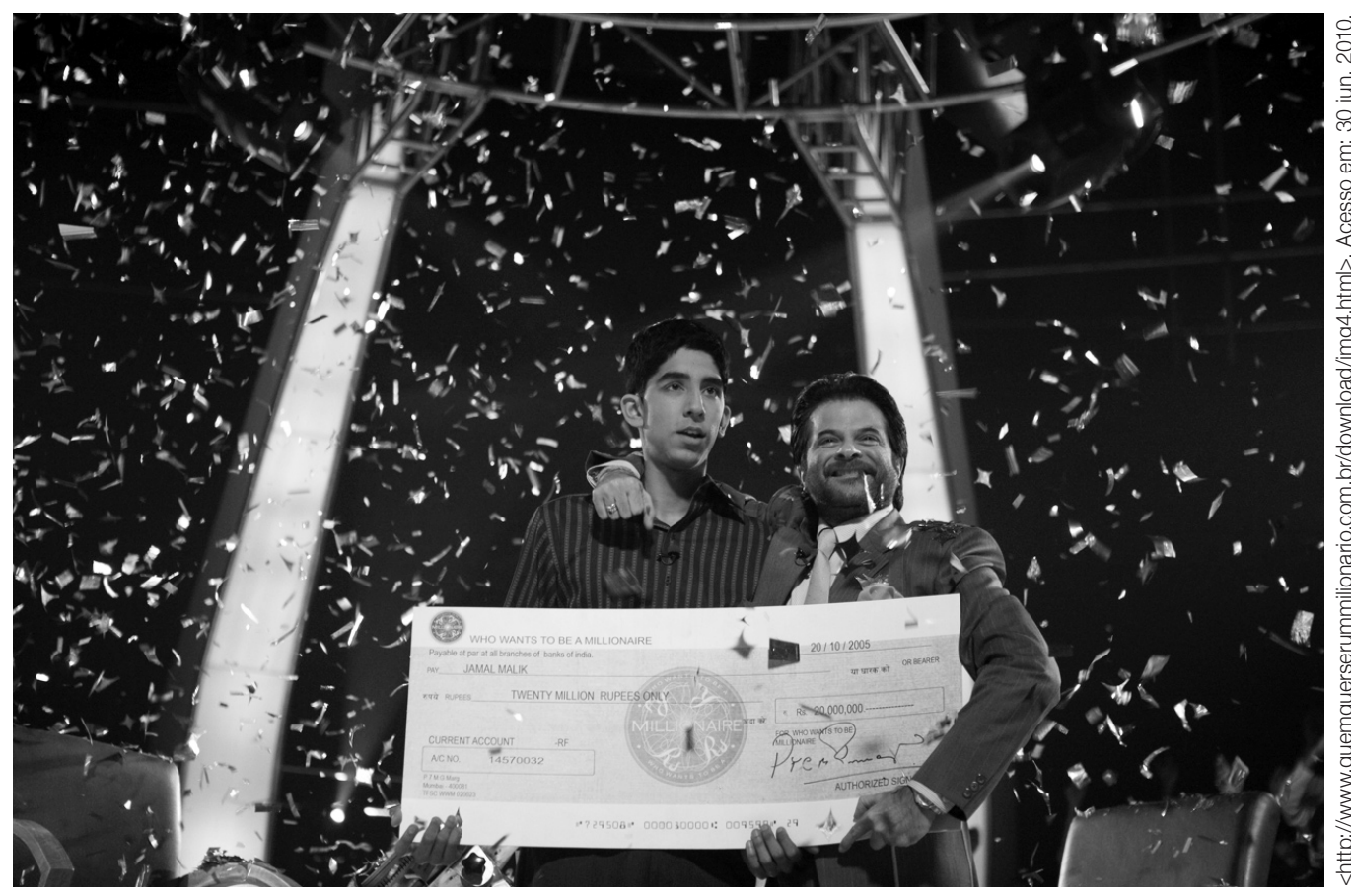

O conhecimento de Jamal é uma metáfora para a experiência cultural de cada sujeito em seu grupo: interesses e objetivos, o dia a dia relacionado com os dados de uma experiência anterior em relação aos gêneros, aos suportes midiáticos, às instituições e aos universos da família, do trabalho, do bairro e da escola.

Para Jamal, jovem apaixonado por Latika, as respostas não são certas ou erradas, porque dizem respeito à cultura de massa da indústria cultural, da qual originam as perguntas do programa. Para ele, são palavras que têm outros sentidos, estão numa trama maior, dizem respeito a experiências de vida. Entram em sintonia com ele pelo valor que possuem no diálogo de momentos específicos da sua vida, de seu irmão e de seus amigos.

O filme pode ser lido como um bom exemplo do que se discute sobre os processos de mediação cultural nos estudos de recepção dos meios de comunicação ${ }^{17}$. A experiência cultural de cada sujeito em seu grupo, mobilizando seus interesses e objetivos, vivendo o dia a dia, relacionando-se com os dados de uma experiência anterior em relação aos gêneros, aos suportes midiáticos, às instituições e aos universos da família, do trabalho, do bairro e da escola, prepara o cenário para a produção de sentidos. A cultura de massa da indústria cultural, exemplificada no programa de auditório do jogo do 
milhão, tem sentido para Jamal porque é a partir dela que pode reencontrar Latika, sua amada.

O filme de Danny Boyle revela o que tão bem nos explica Jesús Martín-Barbero em Dos meios às mediações ${ }^{18}$. As palavras-chave que provocam a memória desafiam e a revelam exatamente porque fazem sentido. Têm sentido porque passam pela mediação das práticas cotidianas da vida do jovem Jamal. Estão inseridas em um contexto que dialogam com a experiência pessoal.

Por que os conteúdos tratados na escola passariam por processos de recepção diferenciados? Como ganham sentido para os jovens alunos as informações obtidas das diferentes áreas de conhecimento? Como captar de Jamal a estratégia para dar a resposta certa? A experiência concreta de vida dos alunos não fica do lado de fora da escola. Conectar os conteúdos escolares ao interesse dos jovens estudantes pressupõe entendê-los como produtores de discursos, em que selecionam, categorizam e organizam, a partir de suas experiências, todos os enunciados que lhes são dirigidos.

A preocupação é mostrar o quanto a escola, espaço da educação, pode ser importante para a construção dos valores sociais. Esse estreitamento entre comunicação e educação permite repensar se os profissionais da educação estão preparados com os instrumentais analíticos e teóricos adequados para a prática diária como comunicadores e educadores. Para exercitar a crítica, precisamos valorizar o papel do sujeito, dar importância às práticas culturais e entender a comunicação como processo de inter-relação social, para daí compreender melhor o momento que estamos vivendo. Os estudos de recepção têm muito a contribuir para isso.

\section{REFERÊNCIAS BIBLIOGRÁFICAS}

BAKHTIN, Mikhail (Voloshinov). Marxismo e filosofia da linguagem. São Paulo: Hucitec, 1988. cap. VI.

FREIRE, Paulo. Pedagogia do oprimido. 17. ed. Rio de Janeiro: Paz e Terra, 1987.

GUIMARÃES JR., Mário José Lopes. Cibercultura e o surgimento de novas formas de sociabilidade. Trabalho apresentado no GT "Nuevos mapas culturales: Cyber espacio y tecnología de la virtualidad”, na II Reunión de Antropología del Mercosur, Piriápolis, Uruguai, de 11 a 14 de novembro de 1997.

LÉVY, Pierre. Revolução virtual. A cibercultura é hoje herdeira legítima das ideias progressistas do Iluminismo. Folha de S. Paulo. 16 ago. 1998. Caderno Mais, p. 3.

MARTÍN-BARBERO, Jesús. Dos meios às mediações: comunicação, cultura e hegemonia. Rio de Janeiro: UFRJ, 1997.

MATTELART. Armand. História das teorias de comunicação. São Paulo: Loyola, 1998.

SCHAFF, Adam. Linguagem e conhecimento. Coimbra: Almedina, 1974.
18. MARTÍN-BARBERO, Jesús. Dos meios às mediações: comunicação, cultura e hegemonia. Rio de Janeiro: UFRJ, 1997. 
comunicação \& educação • Ano XV • número 3 • set/dez 2010

\section{Endereços eletrônicos}

BACCEGA, M. Conhecimento, informação e tecnologia. Comunicação \& Educação, Brasil, v. 4, n. 11, p. 7-16, 1998. Disponível em: <http://www.revistas. univerciencia.org/index.php/comeduc/article/view/4062>. Acesso em: 17 jun. 2009.

. Do mundo editado à construção do mundo. Comunicação \& Educação, Brasil, v. 1, n. 1, 1994. Disponível em: <http://www.revistas.univerciencia.org/ index.php/comeduc/article/view/3867>. Acesso em: 17 jun. 2009.

ESCOBAR, Arturo. Welcome to Cyberia: Notes on the Anthropology of Cyberculture (Bem-vindos à Cyberia: comentários sobre a antropologia da cibercultura). Current Anthropology, v. 35, n. 3, jun. 1994. Disponível em: <http://www.cfh.ufsc.br/ guima/ciber.html\#n4>. Acesso em: 30 jun. 2010. 